\title{
English Abstracts and Keywords
}

Wolfgang Hoffmann-Riem: Media regulation as an objective legal mandate of basic rights (Medienregulierung als objektiv-rechtlicher Grundrechtsauftrag), pp. $175-194$

The freedom of communication encompasses not only the subjective rights of the individual against the state, but also an objective legal mandate for the state to work via the legal order towards ensuring that this basic right can actually be exercised by all persons as a freedom of individual and collective communicative development and political participation. The structural changes in the transition to the information society show that the previous anchoring of subjective rights does not suffice to achieve this goal. Consequently, a recollection of the objective legal mandate of basic rights, which already existed at the beginning of the development of basic rights, is important. Above all, those persons whose power is weak require the protection of rights.

Keywords: media regulation, freedom of communication, convergence, objective legal mandate, regulated selfregulation, censorship

Axel Schmidt: Aggressive humour in the media - with exemplary reference to the television comedy show "TV total” (Aggressiver Humor in den Medien - am Beispiel der Fernseh-Comedy-Show “TV total”), pp. 195 - 226

Stefan Raab's comedy show “TV total” ranks as a prototypical example of more recent development in German television entertainment. The programme has become a symbol for disrespectful provocations and unique confrontations between the presenter and his guests. Whereas critics dismiss the show as a low-quality, smutty and desperately strained form of comedy, its fans praise the way in which television reality and its protagonists are dealt with without taboos. The article here attempts to single out typical characteristics on the basis of an analytical look at individual programme elements in order to determine the specific format of the programme. In a subsequent microanalytical speech linguistics analysis of the way Raab deals with his guests, central strategies of comedy generation are outlined. It is argued that the programme "TV total" mainly builds on the artificial generation of involuntary comedy as a strategy of appeal.

Keywords: humor, comedy, TV comedy, TV entertainment, qualitative media research, communication research, conversation analysis, “TV total”, genre analysis

Holger Schramm / Sven Petersen / Karoline Rütter / Peter Vorderer: How does music get into radio? State and significance of the music research of German radio stations (Wie kommt die Musik ins Radio? Stand und Stellenwert der Musikforschung bei deutschen Radiosendern), pp. 227 - 246

Since the dual broadcasting system was introduced in Germany, there has been a growing formating of radio stations. Music in particular, as a central programme content, defines a station's format and determines its listeners. In order to guarantee a music programme that is optimally tailored to its target group, more and more trust is placed in 
music research figures than in the "gut feeling" of the music editors. The article describes the inadequate state of research on this subject and provides an overview of common music tests applied in commercial radio research. It cites figures on the state and significance of the music research of German radio stations at the beginning of the Nineties and documents two mutually complementary studies reflecting the situation in the year 2001. Finally, the findings are interpreted with respect to the development of music research over the last ten years and the question answered whether music research or the gut feeling of the music editors is viewed as more important for the way music programmes are structured.

Keywords: radio research, music research, music test, radio music, radio music choice, music programme

Edmund Lauf: Freedom for the data! Secondary analysis and data sets in German media and communications research (Freiheit für die Daten! Sekundäranalyse und Datenbestände in der deutschen Medien- und Kommunikationswissenschaft), pp. $247-260$

In media and communications research too, secondary analyses can be much more than a second-class analysis, more than an inexpensive utilisation of residual material. This applies in particular to the analysis of comparable data sets from different countries (spatial) or from different years (temporal). A necessary prerequisite for a secondary-analysis utilisation are available data sets. An analysis of the media and communications research data sets at the Central Archive for Empirical Social Research in Cologne (ZA) shows that media and communications research receives relatively little attention. This is attributable in part to the staff at the media and communications research higher education institutes: a survey revealed that they make only inadequate use of the services of the ZA and that the willingness to make their own data available is very low. In view of the losses of data sets that have already occurred or are to be feared, putting central media and communications research data into archives should be given greater attention in our subject.

Keywords: secondary analysis, media and communications research data, data archives, data sets, Zentralarchiv für Empirische Sozialforschung

Hans W. Giessen: Harold A. Innis - 'Communication' as a key term for the understanding of the history of humankind (Harold A. Innis - ,Kommunikation' als Schlüsselbegriff zum Verständnis der Menschheitsgeschichte?), pp. 261 - 273

Continental Europe first began taking note of the Canadian Harold A. Innis to any noticeable degree as an independent author - and not merely as a generator of ideas for Herbert Marshall McLuhan - in the Nineties. The article begins with a brief intellectual profile and outlines the most important theoretical statements Innis made. It subsequently explains that and why a closer look at the works of Innis could be of special interest today, at the beginning of the 'information society' forecast by many authors (at least: at a time when 'New Media' would appear to be replacing older ones as lead media). A continuation of his theses indicates an interesting new interpretation of our societal reality. The article seeks to make it clear that the ignoring of the works of Innis for 
many years, particularly in Germany and France, is definitely surprising in view of the clear proximity to much-discussed theoretical approaches in both countries. Accordingly, Innis is not viewed as a solitary figure from a more or less marginalized periphery, but represents a specifically Canadian variant of a wider interpretational approach of social theory for his time. Finally, the article discusses possible reasons for the recipience problems the works of Innis not only face in Continental Europe, but fundamentally.

Keywords: philosophy of history, innis, communication: canada, ways of communication, McLuhan, media theory, media effects 